\title{
Studies of Surface Electrical Properties of Al doped ZnO Nanorods by STM
}

\author{
Shaivalini SINGH ${ }^{1}$, Sumit VYAS ${ }^{2}$, Parthasarthi CHAKRABARTI ${ }^{3}$, Si-Hyun PARK ${ }^{1}$ * \\ ${ }^{1}$ Department of Electronic Engineering, Yeungnam University, 280 Daehak-ro, Gyeongsan-si, Gyeongsangbuk-do, 38541 \\ Republic of Korea \\ ${ }^{2}$ Department of Electronics and Communication Engineering, Thapar University, Patiala-147001, India \\ ${ }^{3}$ Department of Electronics Engineering, IIT BHU, Varanasi-221005, India \\ cross ref http://dx.doi.org/10.5755/j01.ms.23.2.15305
}

Received 29 August 2016; accepted 03 October 2016

\begin{abstract}
Pure and aluminum $(\mathrm{Al})$ doped $\mathrm{ZnO}(\mathrm{Al}: \mathrm{ZnO})$ nanorods (NRs) were deposited on silicon substrates by the hydrothermal method. The Al composition was kept at $2 \%$ and $5 \%$ for the Al:ZnO NR samples. The surface morphology and structural properties of the pure and $\mathrm{Al}: \mathrm{ZnO}$ NRs were characterized by scanning electron microscopy (SEM) and X-ray diffraction (XRD), respectively. The XRD study revealed the hexagonal phase of the ZnO with (101), (002) and (100) peaks and it also revealed that the major orientation of ZnO NRs was along the (002) planes. The SEM micrographs showed perfectly grown $\mathrm{ZnO}$ NRs with hexagonal shaped tips. The electrical characterization of the pure and $\mathrm{Al}: \mathrm{ZnO}$ NR thin film surface was done by scanning tunneling microscopy (STM). Local electron spectroscopy was conducted to measure the tunneling current with respect to the applied bias. The $n$-type behavior and bandgap of the pure and $\mathrm{Al}: \mathrm{ZnO}$ NRs were confirmed from the $d I / d V-V$ characteristics. These studies are of fundamental importance for the fabrication of pure and $\mathrm{Al}: \mathrm{ZnO} \mathrm{NR}$ based nanodevices.

Keywords: hydrothermal, $\mathrm{Al}$ doped $\mathrm{ZnO}$, nanorods, scanning tunnelling microscopy, X-ray diffraction.
\end{abstract}

\section{INTRODUCTION}

Among the various transparent conducting oxide (TCO) materials, $\mathrm{ZnO}$ is of particular interest $[1,2]$. It is mainly used in photovoltaic cells, organic light-emitting diodes (OLEDs) and flat panel displays [3-5]. ZnO has a wide optical band gap $(3.37 \mathrm{eV})$, high transparency in visible region, high exciton binding energy $(60 \mathrm{meV})$ and very good conductivity [6]. The properties of $\mathrm{ZnO}$ like electrical conductivity, bandgap and transparency can be tuned and further improved by doping it with different impurities [1,5-7]. Various nanostructures of pure $\mathrm{ZnO}$ and $\mathrm{Al}: \mathrm{ZnO}$ are extensively used, because of their applications in nanogenerators [8], bio-sensors [9], UVsensors [10], nanolasers [11] etc. Different kinds of nanostructures of pure $\mathrm{ZnO}$ and $\mathrm{Al}: \mathrm{ZnO}$ are popular, including nanoparticles [12], nanowires [13], nanotubes [14], and nanorods (NRs) [15]. Al:ZnO NRs are one of the commonly used nanostructures for various devices [3-5]. These NRs can be grown by RF sputtering [16, 17], the sol-gel method [18], dip-coating [19], electrochemical deposition [20], the hydrothermal method [21], and chemical vapor deposition [22], etc. In this work, we used the hydrothermal method for the growth of the $\mathrm{Al}: \mathrm{ZnO}$ NRs.

In order to fabricate $\mathrm{Al}: \mathrm{ZnO} \mathrm{NR}$ based devices, a detailed study of their surface and electronic properties is necessary. In this work, we studied the electronic properties of $\mathrm{Al}: \mathrm{ZnO} \mathrm{NR}$ films using scanning tunneling microscopy (STM). Previously, STM was used to study various semiconductors, such as $\mathrm{ZnS}, \mathrm{SnS}_{2}$ and graphene [23-25]. Few research groups have also reported the STM

\footnotetext{
* Corresponding author. Tel.: +82-53-810-3096.

E-mail address: sihyun_park@ynu.ac.kr (S.-H. Park)
}

studies of $\mathrm{Al}: \mathrm{ZnO}$ thin films deposited by RF-sputtering $[26,27]$. However, till now, no any research group has reported STM studies of Al:ZnO NRs grown by hydrothermal method. In this work, we have systematically examined the structural and electrical properties of pure and $\mathrm{Al}: \mathrm{ZnO} \mathrm{NRs}$. The characteristics of the pure and $\mathrm{Al}: \mathrm{ZnO} \mathrm{NRs}$ samples were investigated by X-ray diffraction (XRD), scanning electron microscopy (SEM) and STM respectively.

\section{EXPERIMENTAL TECHNIQUE}

NR thin films of pure and $\mathrm{Al}: \mathrm{ZnO}$ were grown on $p$ type silicon wafers. All of the wafers were cleaned in acetone and methanol for $10 \mathrm{~min}$ using an ultrasonic bath and then washed with deionized (DI) water. The NRs were grown on Si wafers in two steps. Firstly, a seed layer of pure $\mathrm{ZnO}$ is deposited on the $\mathrm{Si}$ wafer. Then, pure and $\mathrm{Al}: \mathrm{ZnO} \mathrm{NR}$ thin films were grown in the second step, on the previously grown seed layer. Zinc acetate dihydrate powder and ethyl alcohol were used as precursors for the growth of the seed layer. The concentration of seed layer solution was $60 \mathrm{mM}$ and the solution was mixed for one hour at $80^{\circ} \mathrm{C}$ temperature [28]. Zinc nitrate hexahydrate $(\mathrm{ZN})$, hexa-methylene-tetramine (HMT) and DI water were used as precursors for the growth of the pure $\mathrm{ZnO}$ NRs. The concentration of main-growth solution was $30 \mathrm{mM}$ [29]. Aluminum nitrate nonahydrate, ZN, HMT and DI water were used as precursors for the growth of the $\mathrm{Al}$ doped $\mathrm{ZnO}$ NRs. For preparing $\mathrm{Al}$ doped $\mathrm{ZnO}$ NRs samples, 2 wt. $\%$ and 5 wt. $\%$ aluminum nitrate nonahydrate was mixed with ZN, HMT and DI water. The more detail and the principle experimental scheme of the hydrothermal growth setup can be found in the elsewhere [30]. 


\section{CHARACTERIZATION}

The structure of the pure and Al:ZnO NRs was studied using XRD (PAN Analytical X'PERT PRO XRD system with $\mathrm{Cu} \mathrm{K \alpha}$ radiation $(\lambda=1.540568 \AA)$. The surface morphology of the pure and $\mathrm{Al}: \mathrm{ZnO}$ NRs was characterized by SEM (HITACHI S-4800, Japan).

The $I-V$ characteristics of the surface of pure $\mathrm{ZnO}$ and $\mathrm{Al}: \mathrm{ZnO} \mathrm{NR}$ thin films were measured with nanoREV Ambient Air STM system (from Quazar Technologies Pvt. Ltd.). The schematic diagram of STM set-up is shown in the Fig. 1. The STM experiment was done with the tip of Platinum-Iridium. The electrical continuity was maintained during the experiment. A small piece of silver (Ag) paste was used to ground the bottom metallic plate and the surface of $\mathrm{ZnO} \mathrm{NR}$ thin films. The $I-V$ charateristics were measured at already selected places, during the scanning. When the tip reached at that particular locations, the feedback loop was stopped for a while and the current reading was saved. The sample voltage was increased linearly from $-5 \mathrm{~V}$ to $+5 \mathrm{~V}$ in very less time interval ( 100 milli second). The measurement was repeated after a small interval of time. Multiple readings has been taken for each location and with the average of all those reading the resultant curves were obtained.

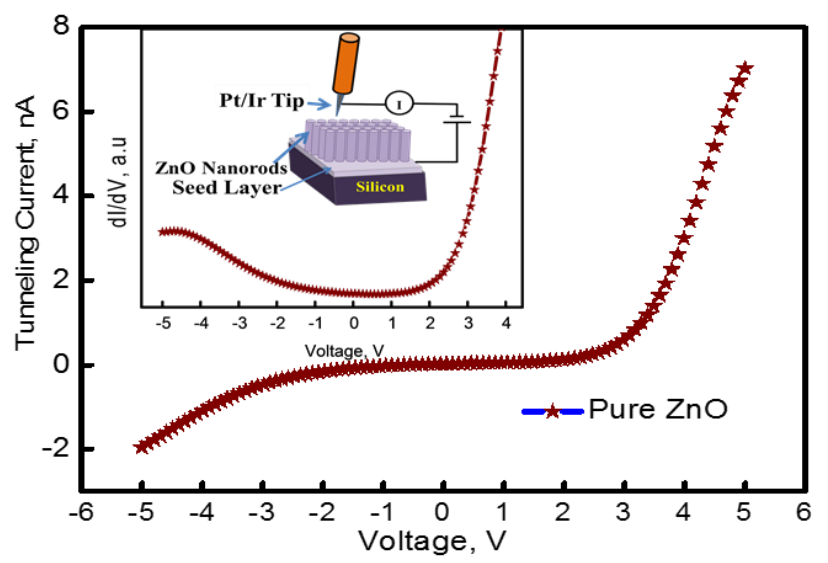

Fig. 1. Scheme of measurement set-up for STM (inset-2); $I-V$ and $d I / d V-V$ (inset-1) characteristics of pure ZnO NR samples measured from STM

\section{RESULTS AND DISCUSSION}

Fig. $2 \mathrm{a}-\mathrm{c}$ shows the XRD patterns of the pure and $2 \%, 5 \% \mathrm{Al}: \mathrm{ZnO} \mathrm{NRs}$ grown on $p$-Si substrates respectively. It shows a wurtzite structure with hexagonal phase and space group, P63mc [31].

The growth of NRs are along (101), (002) and (101) direction, but, the main XRD peak for the pure and $\mathrm{Al}: \mathrm{ZnO}$ NRs corresponding to the (002) orientation. For $5 \% \mathrm{Al}$ doped $\mathrm{ZnO}$, there is also a small peak around $48^{\circ}$, that corresponds to orientation along (102) planes. This means that higher $\mathrm{Al}$ concentrations degrade the crystalline structure of $\mathrm{ZnO}$ NRs. There is no any trace of any other diffraction peaks, such as for $\mathrm{Zn}_{(1-\mathrm{x})} \mathrm{Al}_{\mathrm{x}} \mathrm{O}_{4}, \mathrm{ZnAl}_{2} \mathrm{O}_{4}$ or $\mathrm{Al}_{2} \mathrm{O}_{3}$. This confirms that all of the $\mathrm{Al}^{3+}$ has been successfully substituted for the $\mathrm{Zn}^{2+}$ sites within the $\mathrm{ZnO}$ lattice [32]. Fig. 3 shows the SEM micrographs of the pure and $2 \%$ and $5 \% \mathrm{Al}: \mathrm{ZnO}$ NRs.
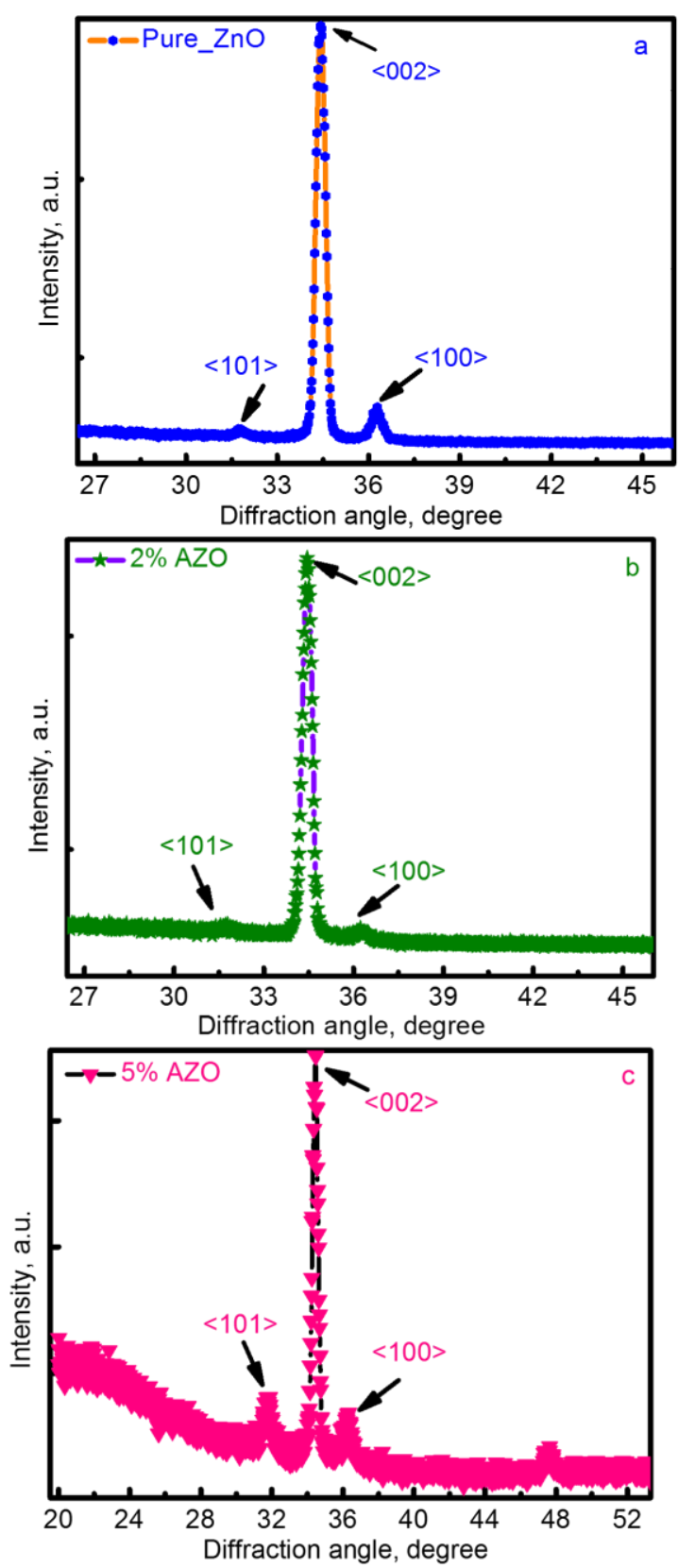

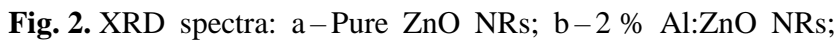
$\mathrm{c}-5 \% \mathrm{Al}: \mathrm{ZnO}$, grown by hydrothermal method

It can be seen that the pure and $\mathrm{Al}: \mathrm{ZnO}$ NRs were successfully grown as vertical-rod like structures with a hexagonal shaped rod-tip. The radius of the tip of the NRs was measured from the SEM images and found to be in the range of 20 to $25 \mathrm{~nm}$. The growth of the NRs was uniform and their density increases with the increase in $\mathrm{Al}$ doping concentration from $0 \%$ (pure) to $5 \%$ [33].

To study the effect of $\mathrm{Al}$ doping on the electrical characteristics of the surface of the pure and Al:ZnO NRs, STM-measurements were performed. A schematic diagram of the STM set-up is shown in the inset of Fig. 1. The voltage was applied in the range of $\pm 5 \mathrm{~V}$ and the tunneling current values were plotted as shown in Fig. 1 and Fig. 4. It can be seen from the graphs that the $I-V$ characteristics are rectifying in nature [34]. This kind of $I-V$ characteristics is mainly due to formation of Schottky contact between the $\mathrm{ZnO}$ and the metal (Pt/Ir) of STM-tip. Earlier Schottky- 
Mott has given one theory, which states that if the electron affinity (EA) of a semiconductor will be smaller than the work function (WF) of the metal, Schottky-contact will be formed [35]. Hence, in our case, the $\mathrm{Pt} / \mathrm{Ir}$ and $\mathrm{ZnO} \mathrm{NRs}$ form a Schottky contact, which gives rise to a nonlinear tunneling current [36]. For $\mathrm{Al}: \mathrm{ZnO}$, the $I-V$ characteristics is less rectifying as compared to $\mathrm{ZnO}$ NRs. This can be attributed to the increase in conductivity of $\mathrm{ZnO}$ by $\mathrm{Al}$ doping.

The STM-conductance characteristics for the Pt/Ir and NRs were also measured, as shown in the insets of Fig. 3 and Fig. 4, respectively. The position $V=0$ in the $d I / d V$ vs. $V$ graph corresponds to the Fermi level, whereas the left and right sides with respect to $V=0$, correspond to the valence-band and conduction-band energy-levels of the semiconductor, respectively [26].
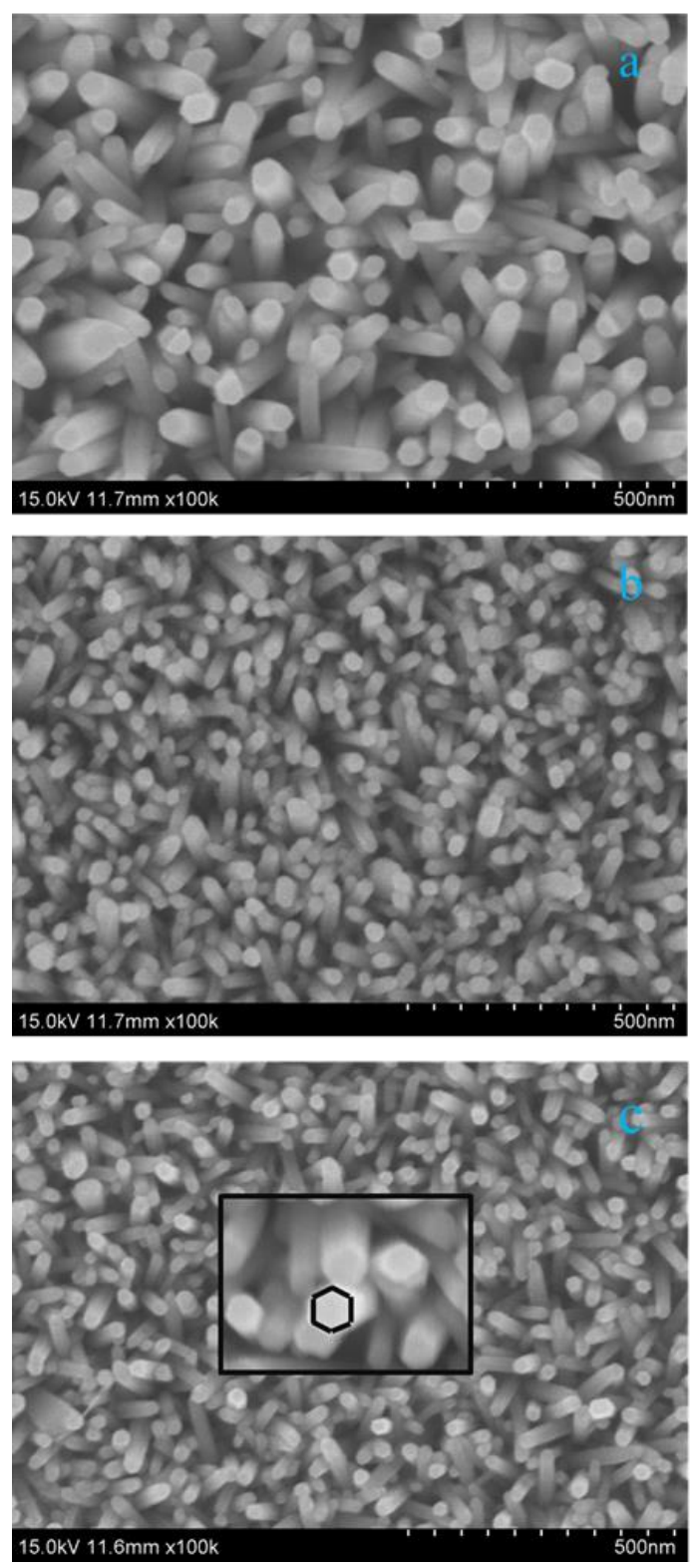

Fig. 3. High-resolution micrograph showing hexagonal-tip of nanorods (inset); SEM image: a-pure ZnO NRs; $b-2 \%$ $\mathrm{Al}: \mathrm{ZnO} \mathrm{NRs} ; \mathrm{c}-5 \% \mathrm{Al}: \mathrm{ZnO}$, grown by hydrothermal method
The $d I / d V$ vs. $V$ graphs in the insets of Fig. 1 and Fig. 4 show that the position of the conduction band is nearer to the Fermi level, which confirms the $n$-type nature of the $\mathrm{ZnO}$. The $d I / d V$ vs. $V$ graphs for $2 \% \mathrm{ZnO} \mathrm{NR}$ samples shows that the Fermi level is closer to conduction band as compared to Fermi level in $\mathrm{ZnO}$ NR samples. The $d I / d V$ vs. $V$ graphs for $5 \% \mathrm{ZnO}$ NR samples reveals that the Fermi level is less closer to conduction band as compared to Fermi level in $2 \% \mathrm{Al}: \mathrm{ZnO}$, but it is more closer as compared to pure $\mathrm{ZnO} \mathrm{NR}$. These $d I / d V$ vs. $V$ graphs were also investigated for the purpose of measuring the bandgap of the undoped and $2 \%$ and $5 \% \mathrm{Al}: \mathrm{ZnO} \mathrm{NR}$ samples. The bandgaps of the pure and $2 \%$ and $5 \%$ $\mathrm{Al}: \mathrm{ZnO} \mathrm{NR}$ surfaces were estimated to be $3.22 \mathrm{eV}$, $3.28 \mathrm{eV}$ and $3.25 \mathrm{eV}$. The increase in the bandgap of $2 \%$ $\mathrm{Al}: \mathrm{ZnO}$ as compared to undoped $\mathrm{ZnO}$ NRs may be due to Burstein-Moss (B-M) effect. The decrease in bandgap of $5 \% \mathrm{Al}: \mathrm{ZnO}$ and as compared to $2 \% \mathrm{Al}: \mathrm{ZnO}$ may be attributed to bandgap narrowing which occurs because of heavy doping.

The thicknesses of the pure and Al: $\mathrm{ZnO}$ NR samples were measured by cross-sectional SEM (not shown here) and found to be $\sim 800-900 \mathrm{~nm}, \sim 300-400 \mathrm{~nm}$ and $\sim 350-400 \mathrm{~nm}$ for the pure $\mathrm{ZnO} \mathrm{NR}$ and $2 \%$ and $5 \%$ $\mathrm{Al}: \mathrm{ZnO} \mathrm{NR}$ samples, respectively. It is noticed that the height of the nanorods were different for pure $\mathrm{ZnO}$ and $\mathrm{Al}: \mathrm{ZnO}$. It can be understood by the facts that the doping of $\mathrm{Al}$ causes reduction in the growth-rate of nanorods. The doping of $\mathrm{ZnO}$ lattice was attained by substitution reaction. The atomic radius of $\mathrm{Zn}$ and $\mathrm{Al}$ are $1.35 \AA$ and $1.25 \AA$ respectively. Probably this difference in the radius causes the difference in the heights of pure $\mathrm{ZnO}$ and $\mathrm{Al}$ : $\mathrm{ZnO}$ naorods [27].

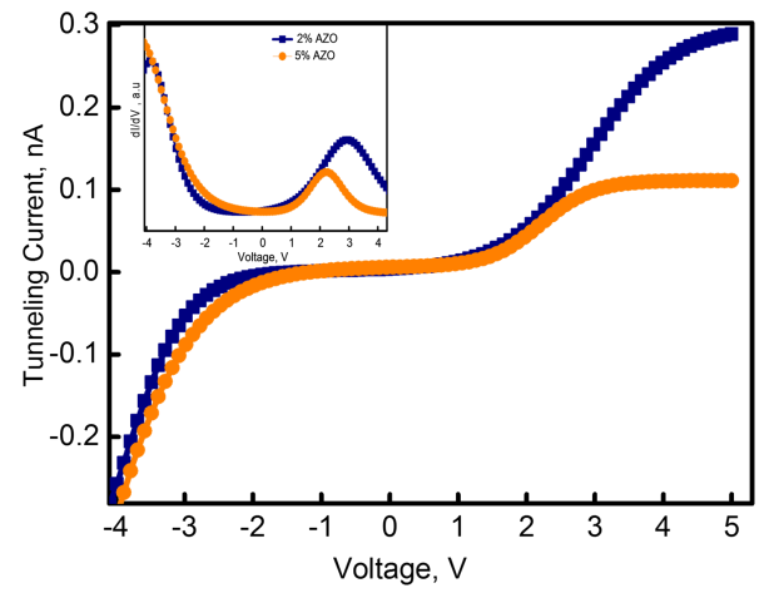

Fig. 4. $I-V$ and $d I / d V-V$ (inset) characteristics of $2 \%$ and $5 \%$ $\mathrm{Al}: \mathrm{ZnO}$ NRs samples measured from STM

\section{CONCLUSIONS}

Pure $\mathrm{ZnO}$ and $2 \%$ and $5 \% \mathrm{Al}: \mathrm{ZnO}$ thin films were grown by the hydrothermal method and their structural and electrical properties were investigated by XRD, SEM, and STM measurements. The XRD patterns of the pure and $\mathrm{Al}: \mathrm{ZnO}$ NRs showed a strong peak for the <002> orientation but the crystalline nature of $\mathrm{ZnO}$ was affected with the increase in $\mathrm{Al}$ concentration. The SEM images of all of the NR films showed that their surface was smooth 
and uniform and density of NRs were found to increase with the increase in $\mathrm{Al}$ concentration. The electrical properties of the surface of the pure and $\mathrm{Al}: \mathrm{ZnO}$ NRs were investigated by STM, and the tunneling current was obtained by applying voltage biases in the range of $-5 \mathrm{~V}$ to $+5 \mathrm{~V}$. The $I-V$ characteristics of the pure and Al:ZnO NRs showed non-linear behavior and the STM conductance spectra were also obtained from the $d I / d V$ vs. $V$ curve. With the help of conductance spectra, the bandgap of pure and $\mathrm{Al}: \mathrm{ZnO} \mathrm{NRs}$ were measured and the bandgap was found to be altered with the incorporation and change in the $\mathrm{Al}$ concentration.

\section{Acknowledgments}

The authors gratefully acknowledge the facilities provided by the Centre for Interdisciplinary Research (CIR) of the institute M.N.N.I.T Allahabad.

\section{REFERENCES}

1. Minami, T. Transparent conducting oxide semiconductors for transparent electrodes Semiconductor Science and Technology 20 2005: pp. S35-S44. https://doi.org/10.1088/0268-1242/20/4/004

2. Stadler, A. Transparent conducting oxides - An up-to-date overview Materials 5 2012: pp. 661-683. https://doi.org/10.3390/ma5040661

3. Lungu, J., Georgescu, A.. Dumbrava, A. Enhancing the efficiency of AZO-based dye sensitized solar cells by surface treatments Scientific Study \& Research 16 2015: pp. 069-074.

4. Li, F., Zhang, Y., Wu, C., Lin, Z., Zhang, B., Guo, T. Improving efficiency of organic light-emitting diodes fabricated utilizing AZO/Ag/AZO multilayer electrode Vacuum 86 2012: pp. 1895-1897. https://doi.org/10.1016/j.vacuum.2012.05.028

5. Liu, Y., Li, Y., Zeng, H. ZnO-based transparent conductive thin films: doping, performance, and processing Journal of Nanomaterials 2013 2013: pp. 1-8.

6. Wang, Z.L. Zinc oxide nanostructures: growth, properties and applications Journal of Physics: Condensed Matter 16 2004: pp. R829-R858.

https://doi.org/10.1088/0953-8984/16/25/R01

7. Jung, K., Shin, D.W., Yoon, S.J., Choi, J.W., Choi, W.K., Song, J.H., Kim, H.J. Electrical and optical properties of Al-doped zinc-oxide thin films deposited at room temperature by using the continuous composition spread method Journal of the Korean Physical Society 57 2010: pp. $1092-1095$.

https://doi.org/10.3938/jkps.57.1092

8. Wang, Z.L. From nanogenerators to piezotronics - A decade-long study of $\mathrm{ZnO}$ nanostructures MRS Bulletin 37 2012: pp 814-827.

https://doi.org/10.1557/mrs.2012.186

9. Bajpai, R., Zaghloul, M., Gu, D., Baumgart. H., Abdel-Fattah, T.M. Synthesis and assembly of $\mathrm{ZnO}$ nanorods grown by ALD for biosensor application Semiconductor Device Research Symposium ISDRS '09, 2009: International, College Park, MD, pp. 1-2.

10. Gedamu, D., Paulowicz, I., Kaps, S., Lupan, O., Wille, S., Haidarschin, G., Mishra, Y.K., Adelung, R. Rapid fabrication technique for interpenetrated $\mathrm{ZnO}$ nanotetrapod networks for fast UV Sensors Advanced Materials 26 2014: pp. $1541-1550$. https://doi.org/10.1002/adma.201304363

11. Chou, Y.H., Chou, B.T., Chiang, C.K., Lai, Y.Y., Yang, C.T., Li, H., Lin, T.R., Lin, C.C., Kuo, H.C., Wang, S.C., Lu, T.C. Ultrastrong mode confinement in $\mathrm{ZnO}$ surface plasmon nanolasers ACS Nano 9 2015: pp. $3978-3983$.

https://doi.org/10.1021/acsnano.5b01643

12. Stypuła, B., Kmita, A., Hajos, M. Morphology and Structure of $\mathrm{ZnO}$ Nanoparticles Produced by Electrochemical Method Materials Science (Medžiagotyra) 20 2014: pp. 3-9.

13. Yang, X., Shan, C.X., Jiang, M.M., Qin, J.M., Hu, G.C., Wang, S.P., Ma, H.A., Jia, X.P., Shen, D.Z. Intense electroluminescence from $\mathrm{ZnO}$ nanowires Journal of Materials Chemistry C 3 2015: pp. 5292-5296. https://doi.org/10.1039/C5TC00317B

14. Fuxue, W., Xiaolong, C., Dawei, Y., Zhaomin, Z., Shaoqing, X., Xiaofeng, G. Synthesis and luminescence characteristics of $\mathrm{ZnO}$ nanotubes Journal of Semiconductors 35 2014: $093004(1-5)$.

15. Sonmez, E., Meral, K. Enhancement of photoluminescence lifetime of $\mathrm{ZnO}$ nanorods making use of thiourea Journal of Nanomaterials 2012 2012: pp. 1-6.

16. Venkatesh, P.S., Dong, C.L., Chen, C.L., Pong, W.F., Asokan, K., Jeganathan, K. Local electronic structure of $\mathrm{ZnO}$ nanorods grown by radio frequency magnetron sputtering Materials Letters 116 2014: pp. 206-208. https://doi.org/10.1016/j.matlet.2013.11.034

17. Her, S.C., Chi, T.C. Optical and electrical performance of $\mathrm{ZnO}$ films textured by chemical etching Materials Science (Medžiagotyra) 21 2015: pp. 502-505.

18. Foo, K.L., Hashim, U., Muhammad, K., Voon, C.H. Sol-gel synthesized zinc oxide nanorods and their structural and optical investigation for optoelectronic application Nanoscale Research Letters 9 2014: pp. 1-10. https://doi.org/10.1186/1556-276X-9-429

19. Schmack, R., Eckhardt, B., Koch, G., Ortel, E., Kraehnert, R. ZnO coatings with controlled pore size, crystallinity and electrical conductivity Materials Science (Medžiagotyra) 22 2016: pp. 74-81.

20. Šulčiūtè, A., Valatka, E. Electrodeposition and photoelectrocatalytic activity of $\mathrm{ZnO}$ films on AISI 304 type steel Materials Science (Medžiagotyra) 18 2012: pp. $318-324$

21. Schlur, L., Carton, A., Lévêque, P., Guillon, D., Pourroy, G. Optimization of a New $\mathrm{ZnO}$ Nanorods hydrothermal synthesis method for solid state dye sensitized solar cells applications Journal of Physical Chemistry C 117 2013: pp. 2993-3001. https://doi.org/10.1021/jp305787r

22. Zhao, R.R., Wei, X.Q., Ding, M., Xu, X.J. Fabrication and Optical Properties of Mg-Doped ZnO Nanorods by Chemical Vapor Deposition Science of Advanced Materials 6 2014: pp. 500-504.

23. Thupakula, U., Bal, J.K., Dalui, A., Debangshi, A., Sarma, D.D., Acharya, S. Current rectification by a single $\mathrm{ZnS}$ nanorod probed using a scanning tunneling microscopic technique Journal of Materials Chemistry $C \quad 2$ 2014: pp. $1158-1164$. https://doi.org/10.1039/c3tc31850h

24. Etefagh, R. Shahtahmasebi, N., Karimipour, M. Effect of $\mathrm{Zn}$ doping on optical properties and photoconductivity of $\mathrm{SnS}_{2}$ nanocrystalline thin films Bulletin Material Science 36 2013: pp. $411-416$. 
https://doi.org/10.1007/s12034-013-0481-0

25. Phark, S.H., Borme, J., Vanegas, A.L., Corbetta, M., Sander, D., Kirschner, J. Scanning tunneling spectroscopy of epitaxial graphene nanoisland on $\operatorname{Ir}(111) \quad$ Nanoscale Research Letters 7 2012: pp. $1-4$.

https://doi.org/10.1186/1556-276X-7-255

26. Likovich, E.M., Jaramillo, R.,

Russell, K.J., Ramanathan, S., Narayanamurti, V. Narrow Band Defect Luminescence from AI-doped $\mathrm{ZnO}$ Probed by Scanning Tunneling Cathodoluminescence Applied Physics Letter 99 2011: pp. $151910(1-3)$.

27. Likovich, E.M., Jaramillo, R., Russell, K.J., Ramanathan, S., Narayanamurti, V. Scanning tunneling microscope investigation of local density of states in Aldoped $\mathrm{ZnO}$ thin films

Physical Review B 83 2011: pp. $075430(1-6)$

28. Singh, S., Park, S.H. Low temperature hydrothermal growth of zno nanorod films for schottky diode application Korean Journal of Metals and Materials 54 2016: pp. 347-351.

29. Nam, G.H., Baek, S.H., Park, I.K. Growth of $\mathrm{ZnO}$ nanorods on graphite substrate and its application for Schottky diode Journal of Alloys and Compounds 613 2014: pp. $37-41$. https://doi.org/10.1016/j.jallcom.2014.05.110

30. Xu, S., Wang, Z.L. One-dimensional $\mathrm{ZnO}$ nanostructures: solution growth and functional properties Nano Research 4 2011: pp. 1013-1098. https://doi.org/10.1007/s12274-011-0160-7
31. Lim, S.K., Hong, S.H., Hwang, S.H., Choi, W.M., Kim, S., Park, H., Jeong, M.G. Synthesis of Al-doped ZnO nanorods via Microemulsion method and their application as a CO gas sensor Journal of Materials Science \& Technology 31 2015: pp. 639-644. https://doi.org/10.1016/j.jmst.2014.12.004

32. Dasgupta, N.P., Neubert, S., Lee, W., Trejo, O., Lee, J.R., Prinz, F.B. Atomic layer deposition of Al-doped $\mathrm{ZnO}$ films: effect of grain orientation on conductivity Chemistry of Materials 22 2010: pp. 4769-4775.

https://doi.org/10.1021/cm101227h

33. Lu, Y.M., Tang, J.F. Electro-optical and structural properties of Al-doped $\mathrm{ZnO}$ nanorod arrays prepared by hydrothermal process International Journal of Science and Engineering 3 2013: pp. 11-15.

34. Brillson, L.J., Lu, Y. ZnO Schottky barriers and Ohmic contacts Journal of Applied Physics 109 2011: pp. $121301(1-33)$.

35. Zeng, Y.J., Schouteden, K. Amini, M.N., Ruan, S.C., Lu, Y.F., Ye, Z.Z., Partoens, B., Lamoen, D., Haesendonck, C.V. Electronic band structures and native point defects of ultrafine zno nanocrystals ACS Applied Materials \& Interfaces 7 2015: pp. 10617-10622. https://doi.org/10.1021/acsami.5b02545

36. Stavale, F., Pascua, L. Nilius, N., $\quad$ Freund, H.J. Morphology and luminescence of $\mathrm{ZnO}$ films grown on a $\mathrm{Au}(111)$ support Journal of Physical Chemistry C 117 2013: pp. $10552-10557$. https://doi.org/10.1021/jp401939x 